\title{
Covering Norway spruce container seedlings with reflective shading cloth during field storage affects seedling post-planting growth
}

\author{
Mikko Tikkinen $^{1}$ (D) Johanna Riikonen ${ }^{2} \cdot$ Jaana Luoranen $^{2}$
}

Received: 1 December 2020 / Accepted: 25 August 2021 / Published online: 3 September 2021

(c) The Author(s) 2021

\begin{abstract}
The field storage of container seedlings is often a necessity after the seedlings have been transported from nurseries close to the regeneration area. Suboptimal storage conditions can lead to reduced growth or even seedling mortality. Supporting favourable conditions for the seedlings during storage requires labour, especially for the watering of seedlings, and therefore increases the costs of forest regeneration. In this study, we examined the effects of covering Norway spruce container seedlings with a reflective shading cloth and neglecting the watering during field storage. This was done by measuring the drying of the seedlings during field storage, the rooting of the seedlings when planting, and the subsequent survival and performance in the field two and three growing seasons after planting. The study comprised one-year-old Norway spruce container seedlings covered with reflective shading cloth and seedlings with no cover (subject to rainfall) in 2012 and 2013; additionally, in 2013, replicates from both treatments were stored in conditions where rainfall was impeded. The stem water potential was measured, a rooting test was carried out, and the seedlings were planted in the test field weekly over 42 days of field storage without watering. As a novel finding, the results indicate that covering the seedlings with a reflective shading cloth during the field storage increased the risk of grey mould in summer storage and led to negative effects regarding post planting seedling development. The application of a shading cloth directly on the seedlings cannot be recommended to prolong the watering intervals during field storage in the current climatic conditions in Southern Finland, where the risk of grey mould is high.
\end{abstract}

Keywords Forest regeneration $\cdot$ Picea abies $\cdot$ Stem water potential $\cdot$ Rooting $\cdot$ Storage stress $\cdot$ Drought

Mikko Tikkinen

mikko.tikkinen@luke.fi

Extended author information available on the last page of the article 


\section{Introduction}

The planting season for Norway spruce container seedlings in Nordic countries lasts from May to September (Luoranen et al. 2019). Dormant, actively growing and short day treated Norway spruce (Picea abies (L.) Karst) seedlings are recommended to be planted in spring (May to mid-June), summer (June to late July) and autumn (August to September), respectively (Luoranen et al. 2005, 2006, 2018; Wallertz et al. 2016). The need to extend the planting season over the summer months, when the seedlings are actively growing and susceptible to drought during storage, is becoming more relevant due to labour shortages and mechanised planting solutions (Helenius 2005; Helenius et al. 2002; Laine et al. 2016; Laine 2017; Ersson et al. 2018).

After delivery from the nursery, seedlings are often kept in field storage in central terminals or close to the regeneration sites in the forest before planting, which is an important part of the seedling supply chain that directly affects the outcome of reforestation (Luoranen et al. 2020). In Finland, the average field storage duration of seedlings is two weeks overall during the planting season, varying from one to 49 days (Rantala et al. 2003). Luoranen et al. (2019, 2020) recommend a field storage period of 1-2 weeks for dormant container seedlings, and two to four days for growing container seedlings. The recommended storage period for actively growing container seedlings is only a few days, because of their high susceptibility to drought stress (Grossnickle and Folk 2003). In both cases, there must be appropriate watering. From field storage, the seedlings are transported to the regeneration site for planting. During the growing season, watering during field storage is required but is often neglected (Rantala et al. 2003).

In field storage, seedlings are often shadowed by trees or buildings, but when kept under direct solar radiation, high temperatures may increase the risk of drought. Drought during storage reduces the root growth and increases the post-planting seedling mortality (Helenius et al. 2005a, b). During field storage, the seedlings are more susceptible to drought than in a nursery, because the watering equipment and monitoring of storage conditions are often quite basic (Rantala et al. 2003). The field performance of seedlings may be assessed using morphological and physiological attributes to define the field performance of seedlings after planting, although several weaknesses have been observed when one or too few attributes are used alone (Puttonen 1986, 1997; Simpson and Ritchie 1997; Grossnickle and MacDonald 2018). Morphological attributes are fairly straight forward to measure, but physiological attributes may more accurately predict the post-planting growth and survival of the seedlings (Grossnickle and MacDonald 2018). The same attributes can be applied to define the field performance after field storage, but the results are rather scarce (Landis et al. 2010; Luoranen et al. 2019).

One option for reducing the need for watering during field storage is to reduce the exposure of the seedlings to direct solar radiation by using a reflective shading cloth (Nyström 1994; Landis et al. 2010). Shading cloths have been used in nurseries and field storage to protect seedlings from direct solar radiation and high and low temperatures (Landis et al. 2010). Shading reduces the water and compensates for temperature fluctuation during storage (Puttonen 1986). Reduced light and decreased ventilation is however known to cause shade avoidance reactions in seedlings and increase the risk of grey mould (Botrytis cinerea Pers. ex Nocca \& Balb) (Smith 1982; Zhang et al. 1995; Petäistö 2006). The previous studies done with shading cloths were done almost 30 years ago. New studies using current stock types and planting periods are needed. In this study, physiological and morphological attributes were used to study the effects of field storage without watering on 
Norway spruce container seedlings, and how covering the seedlings with a reflective shading cloth during storage affected these attributes.

Our aim was to study whether the reflective shading cloth could be used to prevent the drying of the seedlings and to prolong the watering interval without negatively affecting the field performance of Norway spruce container seedlings during field storage in the spring and summer.

\section{Materials and methods}

\section{Plant material and layout of experiments}

The experiments were carried out using one-year-old Norway spruce seedlings of local origin, sown in hard-walled plastic containers (Plantek PL81F, 81 seedlings per tray, volume: $85 \mathrm{~cm}^{3}$, cell surface area: $18.3 \mathrm{~cm}^{2}$, growing density: 546 cells $\mathrm{m}^{-2}$; BCC, Iso-Vimma, Finland), which were filled with base-fertilised $\left(0.8 \mathrm{~kg} \mathrm{~m}^{-3}\right.$ of $16 \mathrm{~N}: 8 \mathrm{P}: 16 \mathrm{~K}$ soluble fertiliser with micronutrients) and limed $\left(2.0 \mathrm{~kg} \mathrm{~m}^{-3}\right)$ light sphagnum peat (Kekkilä Oy, Tuusula, Finland). The seedlings were grown according to Finnish nursery practice for one-year seedlings, using standard fertilisation and irrigation procedures (Rikala 2012). The seeds were sown in late April and the seedlings were grown in a greenhouse until mid-October. They were then moved to an outdoor growing area, where they overwintered under snow cover. The seedlings were packed into top open grid-based trays $(40 \mathrm{~cm}$ by $60 \mathrm{~cm}, 160$ seedlings per tray) for the experiments in 2012. In 2013, the seedlings were kept in their container trays throughout the experiment.

The effects of covering Norway spruce container seedlings with a reflective shading cloth during field storage were studied in three experiments during the 2012 and 2013 growing seasons. The tests were carried out at the Suonenjoki facilities of the Natural Resources Institute Finland (Luke) $\left(62^{\circ} 39^{\prime} \mathrm{N}, 2^{\circ} 03^{\prime} \mathrm{E}\right.$, elevation 142 m.a.s.l.). During 2012, two experiments were carried out between 21 May and 2 July (later referred to as Spring12), and between 9 July and 20 August (later referred to as Summer12). The experiment carried out in 2013 began on 10 June, and the last seedlings, field-stored for 42 days, were planted on 22 July (later referred to as Summer13).

Both experiments conducted in 2012 consisted of 30 test trays split into two storage treatments: seedlings stored under a reflective shading cloth (later referred to as Shading) and seedlings stored without cover (later referred to as Control). Seedlings from both storage treatments were stored in a sandy field. Rainwater interfered with the experiment in 2012, and we therefore simulated drought conditions during storage by excluding rainwater in 2013. In the 2013 experiment, four storage treatments were included: Shading and Control in both an open area and under a plastic roof $(\mathrm{GH}$, greenhouse plastic walls were rolled several metres up so that the plastic roof only prevented rainwater from the top), 15 container trays per treatment, 60 container trays in total. In all experiments, the seedlings were collected for further testing on seven occasions (after $0,7,14,21,28,35$, and 42 days' storage, later referred as the duration of storage).

In all experiments, seedlings undergoing the Shading treatment were covered with a reflective shading cloth, OLS 60 ABRI (Ludvig Svensson AB). The shading cloth was a plastic net with reflective stripes of film, manufactured from polyolefin, aluminium, and polyester, and according to the manufacturer, 39\% of direct solar irradiation and $36 \%$ of indirect solar irradiation penetrated the cloth (Ludvig Svensson AB). During the 
experiments, the penetration of solar irradiation was measured (LI-COR LI-190 SB, LICOR, Inc., Lincoln, USA) in different conditions and was found to be $37 \%$ on average.

\section{Stem water potential and container tray water content}

The stem water potential (SWP) was measured at the beginning of the experiments in 2012 and 2013, and afterwards bi-weekly in 2012 and weekly in 2013, from ten seedlings from each treatment regime. The SWP was measured applying the "pressure chamber method", from the xylem of the shoot tips (4-8 cm below the terminal bud) in megapascals (MPA) (Ritchie and Hinckley 1975).

To determine the container water content (CWC) in all experiments, all the trays were weighed before the outset of the experiments. Three trays per treatment, from which no seedlings had been removed for further testing, were weighed weekly after each storage duration. The container tray water content was determined from the weighing results and the weight of the trays with the saturated substrate. The monthly mean temperature and rainfall between May to August from the years 2012 and 2013 together with the long-term averages are shown in Appendix 1.

\section{Rooting test}

A rooting test was carried out at the beginning of the experiments and bi-weekly thereafter, with 25 randomly selected seedligns per treatment. Each plant was placed in a 0.5 -L pot filled with sand (grain size $\leq 5 \mathrm{~mm}$ ), in which it was grown for 21 days under natural lighting in a greenhouse. The temperature in the greenhouse was set to $21 / 15^{\circ} \mathrm{C}$ (day/night). The pots were randomised in four blocks. The moisture of the sand was kept at $20 \%$ (volumetric), and it was maintained by weighing 8 reference pots, for which an adequate weight after watering was determined. After 21 days, each seedling was removed from the sand, and the root emergence was determined as the number of new roots grown from peat plugs.

\section{Outplanting tests}

After the storage treatments, 30 seedlings per treatment were planted in a cultivated experimental field (fine sand with some organic matter). The seedlings were planted with $0.75-\mathrm{m}$ spacing in seven rows within six blocks (10 seedlings/treatment/block), randomised in a split-plot design. The height (overall, and the length of the current-year shoot) and diameter were measured after planting, and at the end of three consecutive growing seasons. At planting, the state of the apical bud was determined on a scale from 0 (dormant bud) to 7 (needles elongated more than $15 \mathrm{~mm}$ ), and the degree of damage at planting was estimated from 1 (good) to 7 (dead) (Appendix 1). At the end of each growing season, the degree of damage (healthy, slightly damaged, weakened, and dead) and the cause of damage were recorded. Seedlings killed by browsing and mowing were excluded from the data (overall approx. $4 \%$ of seedlings).

\section{Statistical analysis}

Among the experimental treatment combinations, the differences in normally distributed variables - the seedling root emergence, the height and diameter immediately after 
planting, and the height, diameter, and length of the current-year shoot and diameter after the subsequent growing seasons (2012, 2013, and 2014)—were analysed using a linear mixed model (MIXED). The probabilities of damaged or dead seedlings (immediately after planting, and after the 2012, 2013, and 2014 growing seasons) were analysed using a generalised linear mixed model (GENLINMIXED). We employed a binomial distribution with a logit link function in GENLINMIXED models. In the analysis, the storage treatment (treatments located in the GH were considered as individual treatments), duration of storage, and their interaction were considered fixed effects, while the block and duration of storage within the block were random effects. Multiple comparisons were based on the least significant difference.

Nonparametric tests (Mann-Whitney U test in the Spring12 and Summer12 experiments; Kruskal-Wallis test in the Summer13 experiment) were applied to CWC and SWP, because the distributions were not normal. All results were analysed using SPSS Statistics Version 25.0. Differences with a $p \leq 0.05$ were considered significant.

\section{Results}

\section{SWP, water loss during storage}

In Spring12, the main effects of the storage treatment and storage duration treatment on the SWP were not significant (storage treatment $p=0.75$, and duration of storage $p=0.07)$. In Summer12, the main effects of the storage treatment $(p=0.02)$ and the duration of storage $(p<0.01)$ on the SWP were significant. The SWP was lowest for the longest storage duration (Fig. 1a).

In Summer13, the significant interaction between the storage treatment and duration $(p<0.01)$ indicated that the SWP decreased gradually at different rates for different treatments, although the main effects were not significant (Fig. 1a). The decrease in the SWP was more rapid for the GH treatments. After 28 days of storage, measurements from the Control in the GH could no longer be carried out (Fig. 1a). Multiple comparisons showed that the SWP was higher for the treatments stored in the field than in those stored in the greenhouse $(p<0.01$, in all). Additionally, the SWP was higher for the Shading treatment seedlings in the GH than Control treatment seedlings in the GH $(p=0.04)$.

The container tray water content (CWC) differed significantly for the different durations of storage in all experiments $(p<0.01)$. In Spring12, the CWC was lower for the Control treatment than for the Shading treatment after each storage duration $(p \leq 0.05$ in all, except ns after 35 days) (Fig. 1b). In Summer12, during the first 21 days of storage the CWC barely altered, but later the CWC decreased for both storage treatments, but more for the Control treatment ( $p=0.05$ in all).

In Summer13, the CWC varied during storage between the Shading and Control treatments. The CWC differed significantly between storage treatments in all comparisons made for each storage duration ( $p<0.05$ at all measurements) (Fig. 1a). Among the treatments in the $\mathrm{GH}$, the $\mathrm{CWC}$ decreased consistently, but the decrease rate was slower Shading treatment in the GH (Fig. 1b). In multiple comparisons, the CWC for the seedling given the Shading and Control in treatments in the GH were lower overall than the CWC for the Shading and Control treatments otherwise $(p \leq 0.01)$. 


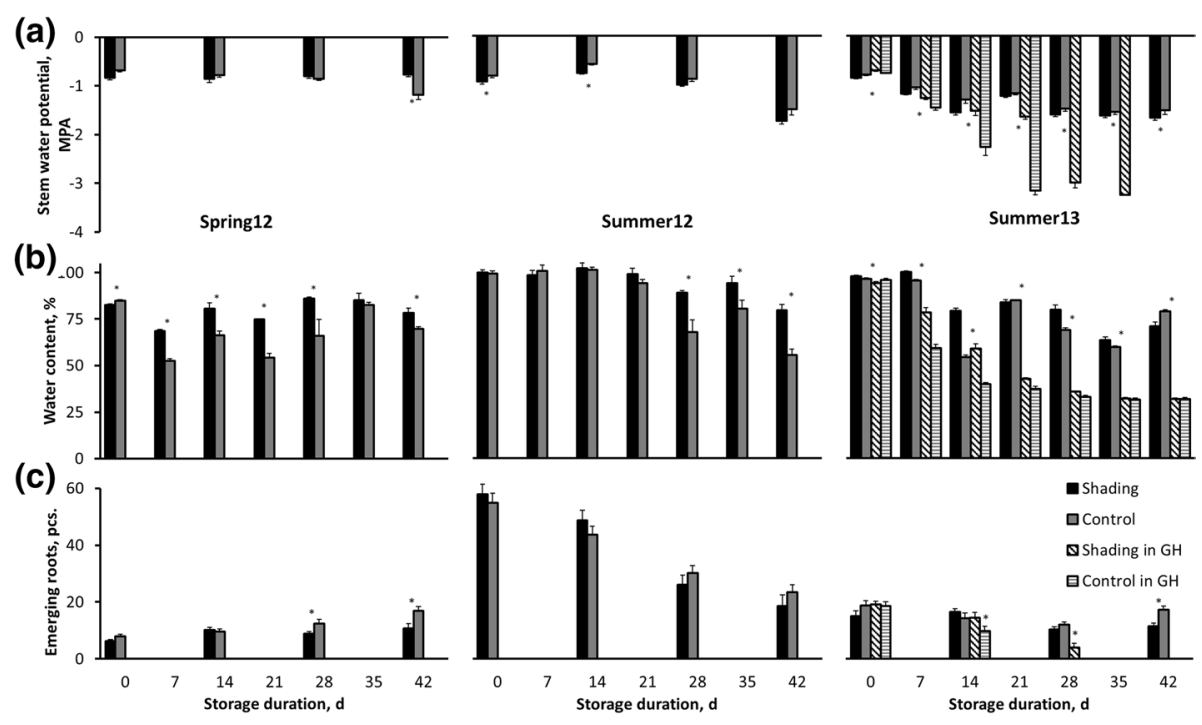

Fig. 1 a Stem water potential (SWP; unit megapascal, MPA), b container water content (\%), and c number of emerging roots in rooting test in different storage treatments and durations of storage in Spring12, Summer12, and Summer13 experiments. The experiments were started in May 2012 (Spring12), July 2012 (Summer12), and June 2013 (Summer13). SWP in the Spring12 and Summer12 experiments, and the number of roots in all experiments, were measured bi-weekly, and SWP weekly in Summer13. Statistically significant $(p \leq 0.05)$ differences between treatments are indicated by *. Mean values are presented with the standard error of the mean (SEM)

\section{Root emergence}

In the rooting test, the number of emerging roots was generally low in the Spring 12 experiment increasing for longer storage durations $(p<0.01)$, especially for the Control treatment $(p<0.05$ in duration of storage, and in the interaction of storage duration and storage treatment). After 28 and 42 days of storage, more roots were found for the Control treatment seedlings than for the Shading treatment seedlings $(p=0.02$, $p<0.01$, respectively).

The highest overall root growth was observed in Summer12, when the root growth gradually decreased $(p<0.01)$. There was no significant difference between the storage treatments ( $p=0.60$; Fig. 1c).

In Summer13, increased storage duration reduced the root emergence $(p<0.01)$ for the GH treatment seedlings (Fig. 1c). The storage treatment and its interaction with the duration of the storage were significant $(p \leq 0.01)$. The poorest root emergence was found for the Control treatment in the $\mathrm{GH}$ after storage durations longer than 14 days [multiple comparisons with other storage treatments $(p \leq 0.03)$ ]. The Control treatment GH seedlings stored for 28 days died during the rooting test $(p<0.01$ in multiple comparisons). After 42 days of storage, seedlings given the Shading treatment in the GH were dead. The root emergence was highest for the Control seedlings after 42 days of storage $(p<0.01)$. 


\section{Seedling growth in the field test}

In Spring12, the seedlings started to grow during the storage period. The longer the storage duration, the thicker and taller the seedlings were at planting (Fig. 2a and 2, Appendix 3).

The effects of the storage duration and its interaction with the storage treatment remained significant for most measurements, even after the third growing season (Fig. 2a, e, Appendix 3). After three growing seasons, the seedlings planted without storage were $33 \%$ taller and had a 55\% larger diameter than seedlings stored for 42 days (Fig. 2a, e, Appendix 3). The seedlings given the Shading treatment stored for 21 days or longer were taller at planting than the seedling which had been given the Control treatment or which had undergone shorter storage durations (Fig. 2e, Appendix 3). However, after the first growing season, the seedlings from the Control treatment stored for 21 days or longer were taller, gaining more height during the second growing season than seedlings which had been given the Shading treatment (Fig. 2e, Appendix 3).

In Summer12, the seedlings grew in height during the storage period (Fig. 2f, Appendix 3 ). The effect of the storage duration was significant throughout the measurements. The seedlings planted without storage were $21 \%$ taller and had a $47 \%$ larger diameter than the seedlings stored for 42 days (diameter and height) (Fig. 2b, 2, Appendix 3). The interactive effect of the storage treatment and duration of storage were significant concerning the plant height at planting and after the first and second growing season. These aspects were also significant to the height growth after the third growing season, and to the seedling diameter immediately after planting and after the second growing season (Fig. 2b, f, Appendix 3). After the second growing season seedlings which had been given the Control treatment were taller than seedlings which had been given the Shading treatment, although at planting the seedlings given the Shading treatment were taller after 35 and 42 days of storage (Fig. 2f, Appendix 3).

In the Summer13 experiment, the seedlings grew in height during the storage period (Fig. 2g, h, Appendix 3). The duration of storage had a significant negative effect on the seedling diameter, height, and current-year shoot in planting and after consecutive growing seasons (Fig. 2c, d, g, 2h, Appendix 3). The seedlings planted without storage were

(a)

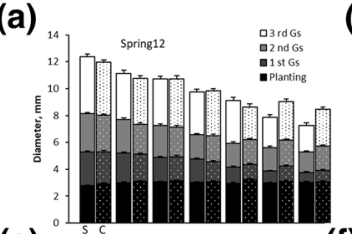

(e)

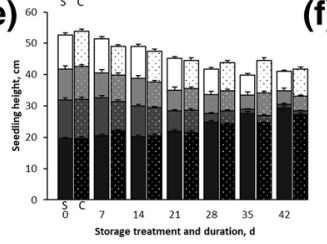

(b)

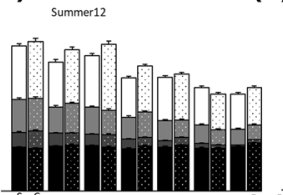

f)

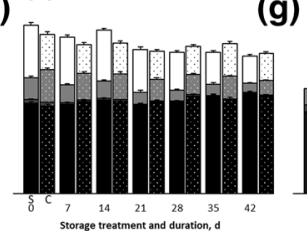

(c)

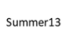

(d)
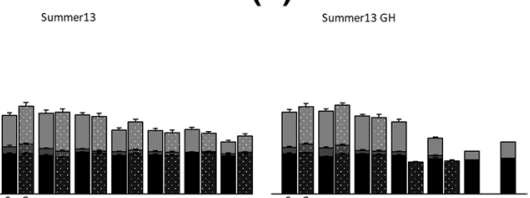

(h)

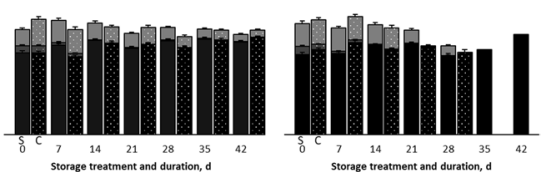

Fig. 2 Seedling $\mathbf{a}-\mathbf{d}$ diameter and $\mathbf{e}-\mathbf{h}$ height at planting and the end of the first to third growing seasons in the a, e Spring 12 and $\mathbf{b}, \mathbf{f}$ Summer12 experiments, and $\mathbf{c}, \mathbf{d}, \mathbf{g}, \mathbf{h}$ at planting and the end first and second growing seasons in the Summer13 experiment. S indicates the Shading treatment; $\mathrm{C}$ indicates the Control treatment without shading (rasterized columns); and GH that the experiment was done under a plastic roof in a greenhouse (in the other experiments, the seedlings were stored in an open field) 
$14 \%$ taller and $52 \%$ thicker than seedlings stored for 42 days after two growing seasons in the field. The effect of the storage duration was more drastic for seedlings given the $\mathrm{GH}$ treatments. The Shading treatment increased the length of the current-year shoot and had a negative effect on the seedling diameter growth during the second growing season, especially for seedling given the GH treatments after 21 days of storage and longer (Figs. 2c, $\mathrm{d}, \mathrm{g} \mathrm{h}$, Appendix 3). The effects of the Shading treatment were further emphasised by the duration of storage on the seedling diameter and height (significant interaction after the first and second growing season, and on height growth after the second growing season) (Fig. 2c, g, Appendix 3).

\section{Seedling damage in the field test}

At planting, nearly all the seedlings in Spring12 were without damage at short storage durations, but the proportion of damaged seedlings increased after 21 days of storage (Fig. 3). After the second growing season, more damaged seedlings were found which had undergone the Shading treatment than the Control treatment $(p<0.01)$, and the proportion of damaged seedlings increased as the storage duration was lengthened $(p<0.01)$ (Fig. 3$)$. No seedling mortality was observed in the Spring 12 experiment at planting. The overall survival after three growing seasons was $98 \%$.

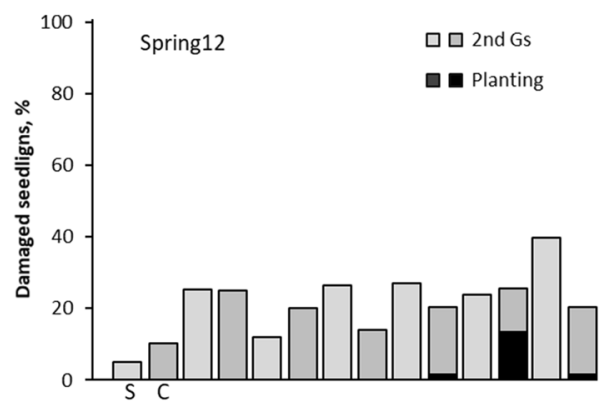

Summer12
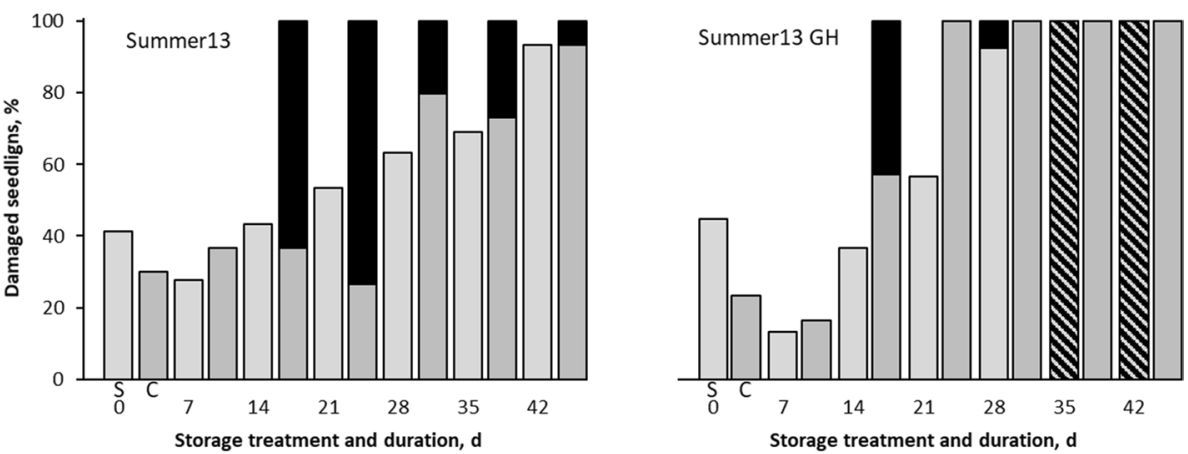

Fig. 3 Percentage of damaged and dead seedlings inventoried at planting and at the end of the second growing season (Gs) in Spring12, Summer12, and Summer13 experiments, where seedlings were either covered with shading cloths $(\mathrm{S})$ or not $(\mathrm{C})$ in an open field or under a plastic roof in the greenhouse (GH) from 0 to 42 days without watering. The rasterized columns indicate identical inventory results in both measurements 
During the Summer12 planting, the proportion of damaged seedlings increased rapidly for seedlings that had undergone both storage treatments after 28 days of storage (for a storage duration $p<0.01$ ). Most of the recorded seedling damage was caused by grey mould infection in the needles in the lower half of the seedlings (Fig. 3). After the first growing season, increasing numbers of slightly damaged needles were observed the longer the storage duration was for both storage treatments (Appendix 3). However, many seedlings had recovered from this damage after the second growing season, while the proportion of damaged seedlings was still related to the storage treatment and duration $(p=0.02$ and $p<0.01$, respectively) (Fig. 3). No seedling mortality was observed in the Summer12 experiment at planting. The overall survival after three growing seasons was $99 \%$.

In Summer13, the duration of storage and its interaction with storage treatment had significant negative effects on seedling damage $(p<0.01$ in both) at planting. The seedlings which had undergone the Shading treatment in open field conditions were nearly undamaged after all storage durations, but for the Control treatment, the proportion of damaged seedlings rapidly increased after 14 days of storage (Fig. 3). However, after the first and second growing season more damaged seedlings were found which had undergone the Shading treatment than the Control treatment when the duration of storage was 14 days or more (Appendix 4, Fig. 3).

For the seedlings which underwent the Control in the $\mathrm{GH}$, the proportion of damaged seedlings at planting rapidly increased after 14 days of storage, and signs of damage were still present after the second growing season (Fig. 3). Overall, more damaged seedlings were found for those seedlings which underwent the Control treatment in the GH compared to other storage treatments $(p<0.01)$ at planting. All the GH Control treatment seedlings and GH Shading treatments were damaged after 21 and 28 days of storage, and most of the damage was still present after the second growing season (Fig. 3).

In the 2013 experiment, at the time of planting, the survival rate for the GH Shading treatment seedlings and GH Control treatment seedlings were 57\% and $42 \%$ respectively. All the seedlings had died during storage under the Control treatment in the GH and the Shading treatment in the $\mathrm{GH}$ after 21 and 28 days of storage, respectively and the seedlings from these treatments were dead after the second growing season $(p<0.01$, interaction of storage treatment and duration of storage in all measurements). Seedling that underwent the Shading and Control treatments, $100 \%$ and $97 \%$ of seedlings were alive at planting respectively. The storage treatments in the $\mathrm{GH}$ significantly differed from each other and from the storage treatments in the open field $(p<0.01)$.

\section{Discussion}

\section{Immediate effects of shading and storage duration}

The results obtained from the CWC and SWP measurements indicate that the use of a shading cloth reduced evaporation, resulting in greater water availability for the seedlings due to higher humidity. Covering the seedlings with a reflective shading cloth during the spring storage had no direct effect on visible seedling damage at planting, when the precipitation was close to the long-term average. In the current study, the stock type planted in spring, i.e. seedlings that had just broken their buds, proved to be more tolerant to the storage stress than the summer stock types (actively growing seedlings at the time of rapid growth), which supports the earlier findings on conifers 
(Grossnickle 2000; Grossnickle and Folk 2003). The stock type planted in the summer has a high level of physical activity and is highly susceptible to drought and freezing, unlike spring stock type before bud break (Grossnickle and Folk 2003).

During the summer storage, when the rainfall was impeded the seedlings dried out slowly, but covering them with a reflective shading cloth slowed down the CWC's decrease rate. The risk of ambient and edaphic drought is at its highest during summer months, when the seedlings are actively growing (Burdett 1990; Grossnickle 2000, 2005; Grossnickle and Folk 2003; Grossnickle et al. 2020; Helenius et al. 2005a; Luoranen et al. 2006). In our study, the weather conditions strongly affected the seedling quality. All seedings were visually damaged after 14 days of storage in summer and dead after 21 days when rainfall was completely impeded.

During high precipitation, covering the seedlings with a reflective shading cloth increased the growth of grey mould; known to thrive in high humidity at a warm temperature, and in low light irradiance (Zhang and Sutton 1994; Zhang et al. 1995; Petäistö 2006; Lilja et al. 2010). During a temporary dry spell, the mould growth remained present among the shaded seedlings, and overwhelmed the seedlings when the humidity increased to a favourable level for the mould. Current findings support the earlier findings by Luoranen et al. (2019) on seedlings stored in closed cardboard boxes.

In the present study, the container tray water content appeared to be more closely related to precipitation, whereas the stem water potential more accurately indicated the seedlings' field performance after storage. These results support the earlier findings by Helenius et al. (2005b), indicating that the xylem water potential more accurately explains seedlings' field performance than the substrate's water content. In this study, a drought during field storage had a direct effect on the seedling quality, and when the drought lasted long enough, also on the survival of the seedlings during field storage, which supports the earlier findings by Helenius et al. (2005b).

Field storage during the summer reduced the number of emerging roots, affecting the seedlings' ability to take in water and nutrients, resulting in reduced field performance (Harper and O'Reilly 2000; Mena-Petite et al. 2001). A favourable water status before planting improves the root growth and field performance of seedlings (Burdett 1990; Larcher 1995). Covering the seedlings with a reflective shading cloth during the spring for 28 days or more reduced the root growth, possibly due to reduced light and precipitation and elevated temperature under the shading cloth. However, during summer storage, when rainfall was impeded, covering the seedlings with a reflective shading cloth supported the emergence of roots after field storage.

The observed increase in root emergence in the Spring12 experiment in springplanted seedlings after lengthening the field storage was probably related to the seedlings' growth rhythm, i.e. the seedlings were dormant, and root growth started during testing (Burdett 1987, 1990; Kaakinen et al. 2004; Luoranen et al. 2006, 2019). Simpson and Ritchie (1997) point out several factors affecting the outcome of root growth tests, such as soil temperature and seedling growth rhythm, which make root growth an unreliable variable for assessing the field performance of seedlings when used alone. Our findings support earlier studies (Puttonen 1997; Simpson and Ritchie 1997), because root growth alone did not completely explain the differences in seedling field performance between the experiments and test years, but it indicated the effects of storage treatments within experiments. 


\section{Effects of shading and storage duration after planting}

Seedlings planted without field storage performed better than seedlings that had undergone field storage. In terms of seedling growth (diameter and height), damage, and survival, the best performing seedlings were stored no longer than seven days. During the summer storage, when precipitation was completely impeded, covering the seedlings with a reflective shading cloth kept the seedlings alive longer than the Control seedlings.

During spring and summer storage in average or high precipitation, more damage was found after the second growing season for those seedlings which had been covered with a reflective shading cloth. The findings regarding the delayed effects on seedlings after planting due to a reflective shading cloth are novel. No severe mould infestation was found during the spring storage.

In the final measurements, covering seedlings with a reflective shading cloth increased the height growth of seedlings at the expense of diameter growth during the first three weeks of field storage during average or high precipitation. When rainfall was impeded, covering seedlings with a reflective shading cloth reduced seedling damage and mortality when the field storage lasted three weeks or longer. Increased shoot height growth of Norway spruce seedlings during storage in closed cardboard boxes due to storage has been reported by Luoranen et al. (2019), indicating a seedling response to maximise the intake of light energy in scarce light conditions (Smith 1982).

Even field storage of seven days had a negative effect on seedlings' field performance when irrigation was neglected. These seedlings grew about $5 \%$ less in height and up to $11 \%$ less in diameter after two or three years in the field. These results highlight the importance of reducing storage stress, e.g. by implementing sufficient watering regimes, as concluded in previous studies (Mattson 1986, 1992; Helenius et al. 2002; Grossnickle and Folk 2003). Additionally, the seedling nitrogen content during storage may have been reduced, as seedlings started growing or were already growing when the field storage began (Ericsson et al. 1983), but this was unfortunately not determined in this study. Additionally, the storage reserves of nutrients and carbohydrates may have varied between stock types, being possibly lower in dormant seedlings (van den Driessche 1992).

\section{Conclusions and future prospects}

Storing seedlings near the regeneration site is often a necessity, and negative effects on seedling survival and growth may occur due to storage. In the present study, field storage without watering had a negative effect on the xylem water potential and root emergence. This resulted in the decreased height and diameter growth of seedlings up to three growing seasons after planting in the field, and increased the proportion of damaged seedlings, especially for longer storage durations. Covering the seedlings with a reflective shading cloth reduced the seedlings' evaporation and drying during low precipitation, but it increased the risk of grey mould during high and average precipitation. When the precipitation was completely impeded, covering seedlings with a reflective shading cloth reduced seedling damage and mortality.

We conclude, that in the current climatic conditions in Southern Finland, covering Norway spruce container seedlings with a reflective shading cloth cannot be recommended without daily supervision. The current results may be generalized to other conifers and 
seedling types stored in similar conditions. The cost-efficiency of maintaining the field storage site could possibly be improved by developing an automated surveillance system or other technological approach which needs to be considered in future studies.

\section{Appendix 1}

Monthly mean temperature $\left({ }^{\circ} \mathrm{C}\right)$ and rainfall $(\mathrm{mm})$ between May and August in Long term (1976-2011), in 2012 and 2013.

\begin{tabular}{lllllllll}
\hline Month & \multicolumn{2}{l}{ Mean temperature $\left({ }^{\circ} \mathrm{C}\right)$} & & \multicolumn{3}{l}{ Mean rainfall $(\mathrm{mm})$} \\
\cline { 2 - 3 } & $1976-2011$ & 2012 & 2013 & & $1960-2011$ & 2012 & 2013 \\
\hline May & 9.2 & 9.7 & 12.7 & & 41 & 73 & 18 \\
June & 14.2 & 13.0 & 17.9 & & 66 & 95 & 43 \\
July & 16.6 & 16.8 & 16.5 & & 86 & 137 & 75 \\
August & 14.4 & 14.0 & 15.8 & & 74 & 48 & 118 \\
\hline
\end{tabular}

\section{Appendix 2}

Classification of apical buds on a scale from 0 (dormant bud) to 7 (needles elongated more than $15 \mathrm{~mm}$ ) and condition of seedlings on scale from 1 (good) to 7 (dead) applied in the experiments.

\begin{tabular}{lll}
\hline Class & State of apical bud & Condition of seedling \\
\hline 0 & Dormant bud & \\
1 & Bud slightly swollen & Good \\
2 & Bud swollen, needles covered by the bud scales & Brown needles at the lower half of the stem \\
3 & Bud scales lacerated, needles not elongated & Brown needles at the top half of the stem \\
4 & Needles elongated ca $5 \mathrm{~mm}$ but not diffused & Mould at the lower half of the stem \\
5 & Needles elongated 5-10 mm, needles diffused & Mould at the top half of the stem \\
6 & Needles elongated $10-15 \mathrm{~mm}$, needles diffused & Mechanical stem damage, i.e. stem breakage \\
7 & Needles elongated $\geq 15 \mathrm{~mm}$, needles diffused & Dead \\
\hline
\end{tabular}

\section{Appendix 3}

$P$ values of seedling diameter, diameter growth, height, and height growth after planting, after the first and second growing season (Gs) 2012, 2013, and after the third growing season in the Spring12, Summer12, and 2013 experiments, presented in different storage treatments, duration of storage and their interaction (Interaction) overall. 


\begin{tabular}{|c|c|c|c|c|c|c|c|c|c|c|}
\hline \multirow{2}{*}{$\begin{array}{l}\text { Meas- } \\
\text { ure- } \\
\text { ment }\end{array}$} & \multirow{2}{*}{$\begin{array}{l}\text { Measure- } \\
\text { ment }\end{array}$} & \multicolumn{3}{|c|}{ Spring12 } & \multicolumn{3}{|c|}{ Summer12 } & \multicolumn{3}{|l|}{2013} \\
\hline & & $\begin{array}{l}\text { Treat- } \\
\text { ment }\end{array}$ & $\begin{array}{l}\text { Dura- } \\
\text { tion }\end{array}$ & $\begin{array}{l}\text { Interac- } \\
\text { tion }\end{array}$ & $\begin{array}{l}\text { Treat- } \\
\text { ment }\end{array}$ & $\begin{array}{l}\text { Dura- } \\
\text { tion }\end{array}$ & $\begin{array}{l}\text { Interac- } \\
\text { tion }\end{array}$ & $\begin{array}{l}\text { Treat- } \\
\text { ment }\end{array}$ & $\begin{array}{l}\text { Dura- } \\
\text { tion }\end{array}$ & $\begin{array}{l}\text { Interac- } \\
\text { tion }\end{array}$ \\
\hline \multirow{2}{*}{$\begin{array}{l}\text { Plant- } \\
\text { ing }\end{array}$} & Diameter & 0.00 & 0.27 & 0.50 & 0.06 & 0.06 & 0.03 & $<0.01$ & $<0.01$ & $<0.01$ \\
\hline & Height & 0.02 & $<0.01$ & $<0.01$ & 0.75 & $<0.01$ & 0.02 & 0.02 & $<0.01$ & $<0.01$ \\
\hline \multirow[t]{4}{*}{ 1st Gs } & Diameter & 0.67 & $<0.01$ & 0.01 & 0.02 & $<0.01$ & 0.07 & 0.09 & $<0.01$ & 0.03 \\
\hline & $\begin{array}{c}\text { Diameter } \\
\text { growth }\end{array}$ & 0.18 & $<0.01$ & 0.01 & 0.42 & $<0.01$ & 0.18 & 0.25 & $<0.01$ & 0.45 \\
\hline & Height & 0.01 & $<0.01$ & 0.02 & 0.99 & 0.01 & 0.01 & 0.06 & 0.03 & $<0.01$ \\
\hline & $\begin{array}{l}\text { Height } \\
\text { growth }\end{array}$ & 0.66 & $<0.01$ & $<0.01$ & 0.72 & $<0.01$ & 0.75 & 0.23 & $<0.01$ & 0.85 \\
\hline \multirow[t]{4}{*}{ 2nd Gs } & Diameter & 0.43 & $<0.01$ & 0.00 & 0.26 & $<0.01$ & 0.01 & 0.02 & $<0.01$ & 0.01 \\
\hline & $\begin{array}{c}\text { Diameter } \\
\text { growth }\end{array}$ & 0.79 & $<0.01$ & 0.05 & 0.64 & 0.00 & 0.13 & & & \\
\hline & Height & 0.94 & $<0.01$ & 0.75 & 0.10 & $<0.01$ & 0.05 & 0.36 & $<0.01$ & $<0.01$ \\
\hline & $\begin{array}{l}\text { Height } \\
\text { growth }\end{array}$ & 0.01 & $<0.01$ & 0.09 & 0.02 & $<0.01$ & 0.30 & 0.03 & $<0.01$ & 0.02 \\
\hline \multirow[t]{4}{*}{ 3rd Gs } & Diameter & 0.50 & $<0.01$ & 0.00 & 0.02 & $<0.01$ & 0.44 & & & \\
\hline & $\begin{array}{c}\text { Diameter } \\
\text { growth }\end{array}$ & 0.33 & $<0.01$ & 0.00 & 0.06 & 0.00 & 0.74 & & & \\
\hline & Height & 0.36 & $<0.01$ & 0.04 & 0.58 & $<0.01$ & 0.30 & & & \\
\hline & $\begin{array}{l}\text { Height } \\
\text { growth }\end{array}$ & 0.07 & 0.00 & $<0.01$ & 0.08 & $<0.01$ & 0.02 & & & \\
\hline
\end{tabular}

\section{Appendix 4}

Percentage of damaged seedlings inventoried at planting and at the end of the first to third growing seasons (Gs) in Spring12, Summer12, and Summer13 experiments, where seedlings were either covered with shading cloths (Shading) or not (Control) outdoors or under a plastic roof in the greenhouse $(\mathrm{GH})$ from 0 to 42 days without watering. 


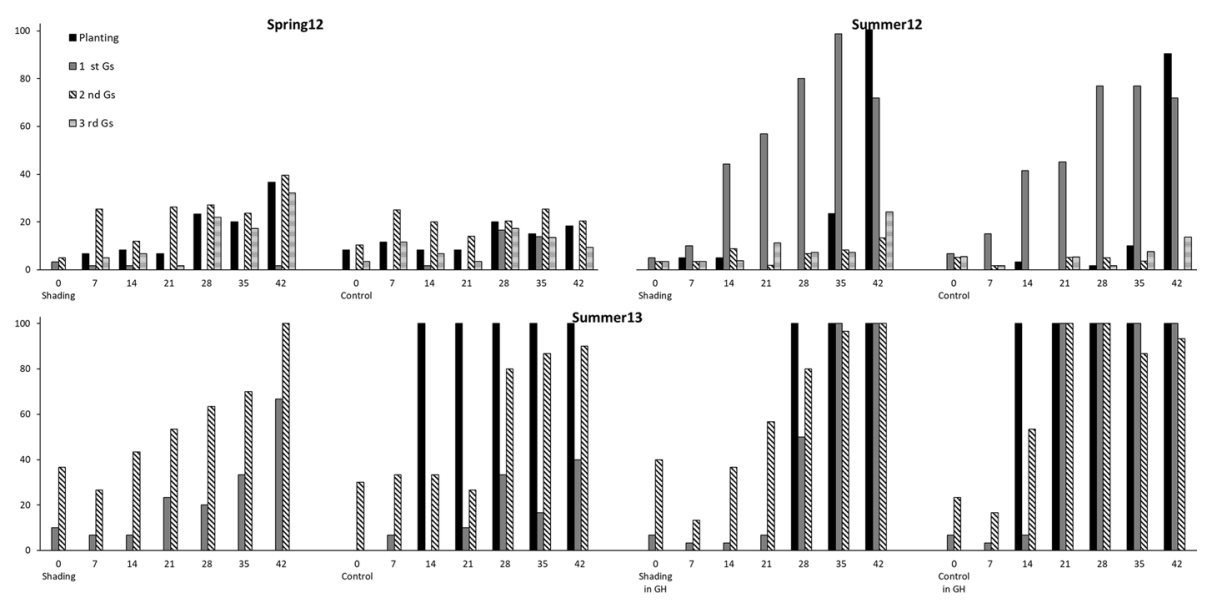

Acknowledgements The authors wish to thank Luke's Suonenjoki staff (METLA at the time of the experiments), especially Pekka Voipio and Auli Lehtinen for their irreplaceable expertise and technical assistance during the experiments. The authors would like to acknowledge and thank Heikki Smolander, who was the initiative force behind this this work. The corresponding author would also like to acknowledge Ohto Salo for his assistance and peer support during the experiments.

Author's contribution MT participated in the study's planning and data analysis and had the main responsibility for the experimental set-up and measurements, and for writing the manuscript. JR participated in the planning of the experimental set-up for the study in all experiments (including data measurements and analyses) and in the writing of the manuscript. JL had the main responsibility for planning and data analysis and participated in writing the manuscript.

Funding This research was funded by the European Social Fund - Finland (ESF, project S11890) and the Natural Resources Institute Finland (Projects 3554, 41007-00100100). Open access funding provided by Natural Resources Institute Finland (LUKE).

\section{Declarations}

Conflict of interest The authors declare that they have no conflicts of interest.

Open Access This article is licensed under a Creative Commons Attribution 4.0 International License, which permits use, sharing, adaptation, distribution and reproduction in any medium or format, as long as you give appropriate credit to the original author(s) and the source, provide a link to the Creative Commons licence, and indicate if changes were made. The images or other third party material in this article are included in the article's Creative Commons licence, unless indicated otherwise in a credit line to the material. If material is not included in the article's Creative Commons licence and your intended use is not permitted by statutory regulation or exceeds the permitted use, you will need to obtain permission directly from the copyright holder. To view a copy of this licence, visit http://creativecommons.org/licenses/by/4.0/.

\section{References}

Burdett AN (1987) Understanding root growth capacity: theoretical considerations in assessing planting stock quality by means of growth tests. Can J for Res 17(8):768-775. https://doi.org/10.1139/x87-123

Burdett AN (1990) Physiological processes in plantation establishment and the development of specifications for forest planting stock. Can J for Res 20:415-427. https://doi.org/10.1139/x90-059 
Ersson BT, Laine T, Saksa T (2018) Mechanized tree planting in Sweden and Finland: current state and key factors for future growth. Forests 9(7):370. https://doi.org/10.3390/f9070370

Grossnickle SC (2000) Ecophysiology of northern spruce species: the performance of planted seedlings. NRC Research Press, Ottawa

Grossnickle SC (2005) Importance of root growth in overcoming planting stress. New for 30:273-294. https://doi.org/10.1007/s11056-004-8303-2

Grossnickle SC, Folk RS (2003) Spring versus summer spruce stocktypes of Western Canada: nursery development and field performance. West J Appl for 18(4):267-275. https://doi.org/10.1093/wjaf/18.4. 267

Grossnickle SC, MacDonald JE (2018) Why seedlings grow: influence of plant attributes. New for 49:1-34. https://doi.org/10.1007/s11056-017-9606-4

Grossnickle SC, Kiiskila SB, Haase DL (2020) Seedling ecophysiology: five questions to explore in the nursery for optimizing subsequent field success. Tree Plant Notes 63(2):112-127

Harper CP, O'Reilly C (2000) Effect of warm storage and date of lifting on the quality of Douglas-fir seedlings. New for 20:1-13. https://doi.org/10.1023/A:1006716406147

Helenius P (2005) Extension of the planting period of Norway spruce container seedlings: risks related to the drought-growth stage dynamics and handling practices. Diss for. https://doi.org/10.14214/df.3

Helenius P, Luoranen J, Rikala R, Leinonen K (2002) Effect of drought on growth and mortality of actively growing Norway spruce container seedlings planted in summer. Scand J for Res 17(3):218-224. https://doi.org/10.1080/028275802753742882

Helenius P, Luoranen J, Rikala R (2005a) Physiological and morphological responses of dormant and growing Norway spruce container seedlings to drought after planting. Ann for Sci 62(2005):201-207. https://doi.org/10.1051/forest:2005011

Helenius P, Luoranen J, Rikala R (2005b) Effect of pre-planting drought on survival, growth and xylem water potential of actively growing Picea abies container seedlings. Scand J for Res 20(2):103-109. https://doi.org/10.1080/02827580510008239

Kaakinen S, Jolkkonen A, Iivonen S, Vapaavuori E (2004) Growth, allocation and tissue chemistry of Picea abies seedlings affected by nutrient supply during the second growing season. Tree Physiol 24:707719. https://doi.org/10.1093/treephys/24.6.707

Laine T (2017) Mechanized tree planting in Finland and improving its productivity. Diss for. https://doi.org/ $10.14214 / \mathrm{df} 239$

Laine T, Kärhä K, Hynönen A (2016) A survey of the Finnish mechanized tree-planting industry in 2013 and its success factors. Silva Fennica 50(2):1323. https://doi.org/10.14214/sf.1323

Landis TD, Dummroese RK, Haase DL (2010) The container tree nursery manual, vol 7. Seedling processing, storage and outplanting. U.S. Department of Agriculture, Forest Service. Agricultural Handbook, Washington, DC, p 674.

Larcher W (1995) Physiological plant ecology: ecophysiology and stress physiology of functional groups, 4th edn. Springer, Berlin

Lilja A, Poteri M, Petäistö RL, Kurkela T, Kasanen R (2010) Fungal diseases in forest nurseries in Finland. Silva Fennica 44(3):525-545. https://doi.org/10.14214/sf.147

Luoranen J, Helenius P, Rikala R, Konttinen K, Smolander H (2005) Extending the planting period of dormant and growing norway spruce container seedlings to early summer. Silva Fennica 39(4):481-496. https://doi.org/10.14214/sf.361

Luoranen J, Helenius P, Rikala R, Konttinen K, Smolander H (2006) Summer planting of Picea abies container-grown seedlings: effects of planting date on survival, height growth and root egress. For Ecol Manag 237(2006):534-544. https://doi.org/10.1016/j.foreco.2006.09.073

Luoranen J, Saksa T, Lappi J (2018) Seedling, planting site and weather factors affecting the success of autumn plantings in Norway spruce and Scots pine seedlings. For Ecol Manag 419-420:79-90

Luoranen J, Pikkarainen L, Poteri M, Peltola H, Riikonen J (2019) Duration limits on field storage in closed cardboard boxes before planting of Norway spruce and scots pine container seedlings in different planting seasons. Forests 10:1126. https://doi.org/10.3390/f10121126

Luoranen J, Saksa T, Uotila K (2020) Metsänuudistaminen. Metsäkustannus. Bookwell Oy. Porvoo

Mattson WJ (1986) Planting site storage: effects on survival and growth of overwinter-stored Scots pine (Pinus sylvestris) containerized seedlings. Can J for Res 16(1):84-89. https://doi.org/10.1139/x86-014

Mattson WJ (1992) The dilemma of plants: to grow or defend. Q Rev Biol 67(3):283-335

Mena-Petite A, Ortega-Lasuen U, González-Moro MB, Lacuesta M, Muñoz-Rueda A (2001) Storage duration and temperature effect on the functional integrity of container and bare-root Pinus radiata D. Don stock-types. Trees 15:289-296. https://doi.org/10.1007/s004680100104 
Nyström C (1994) Lagring inför maskinell plantering. Plantnytt: Institutionen för Skogsproduktion. Sveriges lantbruksuniversitet, institutionen för skogsproduktion avd skogsförnyelse. Hammars tryckeri, Säter

Petäistö RL (2006) Botrytis cinerea and Norway spruce seedlings in cold storage. Balt for 11(3):24-44

Puttonen P (1986) Carbohydrate reserves in Pinus sylvestris seedling needles as an attribute of seedling Vigor. Scand J for Res 1(3):181-193. https://doi.org/10.1080/02827588609382410

Puttonen P (1997) Looking for the "silver bullet" — can one test do it all? New for 13:9-27. https://doi.org/ 10.1023/A:1006557502326

Rantala J, Rikala R, Viitarinne E Leinonen TA (2003) Taimien matka taimitarhalta istutuskohteelle kysely-ja haastattelututkimus. Metsätieteen aikakauskirja 4/2003 417-427. https://doi.org/10.14214/ ma.6108

Rikala R (2012) Metsäpuiden paakkutaimien kasvatusopas. Vammalan kirjapaino

Ritchie GA, Hinckley TM (1975) The pressure chamber as an instrument for ecological research. Adv Ecol Res 9:165-254

Simpson DG, Ritchie GA (1997) Does RGP predict field performance? A debate. New for 13:249-273. https://doi.org/10.1023/A:1006542526433

Smith H (1982) Light quality, photoperception, and plant strategy. Annu Rev Plant Physiol 33:481-518. https://doi.org/10.1146/annurev.pp.33.060182.002405

Svensson. [www-sivusto]. AB Ludvig Svensson. https://www.ludvigsvensson.com/en/climate-screens/. Viitattu 7 Oct 2020

van den Driessche R (1992) Changes in drought resistance and root growth capacity of container seedlings in response to nursery drought, nitrogen, and potassium treatments. Can J for Res 22(5):740-749. https://doi.org/10.1139/x92-100

Wallertz K, Hansen KH, Hjelm K, Fløistad IS (2016) Effect of planting time on pine weevil (Hylobius abietis) damage to Norway spruce seedlings Scandinavian. J for Res 31(3):262-270. https://doi.org/10. $1080 / 02827581.2015 .1125523$

Zhang PG, Sutton JC (1994) High temperature, darkness, and drought predispose black spruce seedlings to gray mold. Can J Bot 72:135-142. https://doi.org/10.1139/b94-018

Zhang PG, Sutton JC, Hopkin AA (1995) Low light intensity predisposes black spruce seedlings to infection by Botrytis cinerea. Can J Plant Path 17:13-18. https://doi.org/10.1080/07060669509500714

Publisher's Note Springer Nature remains neutral with regard to jurisdictional claims in published maps and institutional affiliations.

\section{Authors and Affiliations}

\section{Mikko Tikkinen $^{1}$ (D) . Johanna Riikonen ${ }^{2} \cdot$ Jaana Luoranen $^{2}$}

Johanna Riikonen

johanna.riikonen@luke.fi

Jaana Luoranen

jaana.luoranen@luke.fi

1 Production Systems, Natural Resources Institute Finland (Luke), Vipusenkuja 5, 57200 Savonlinna, Finland

2 Production Systems, Natural Resources Institute Finland (Luke), Juntintie 154, 77600 Suonenjoki, Finland 